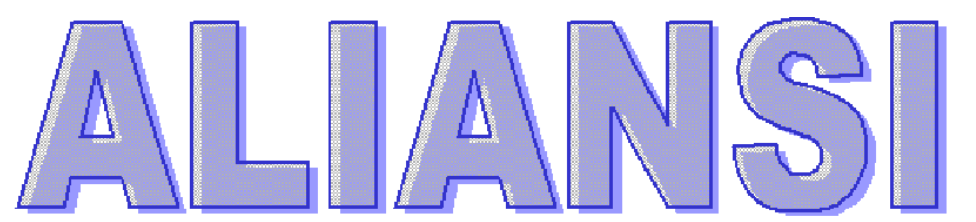

P-ISSN : 2622-562X

e-ISSN : $\underline{2722-5828}$

PROGRAM STUDI AKUNTANSI

FAKULTAS EKONOMI

IURNAL AKUNTANSI

UNIVERSITAS GUNUNG RINJANI

DAN KEUANGAN SYARIAH

\title{
PENGARUH STRUKTUR MODAL, ARUS KAS DAN PIUTANG TERHADAP PAJAK PENGHASILAN
}

\author{
Siti Reuni Inayati ${ }^{1}$, Reny Wardiningsih ${ }^{2}$ \\ Universitas Gunung Rinjani ${ }^{1}$, Universitas Teknologi Mataram ${ }^{2}$ \\ reuniku09@gmail.com¹,reny.wardi@yahoo.com ${ }^{2}$
}

\begin{abstract}
Penelitian ini bertujuan untuk mengetahui struktur modal, arus kas, dan piutang terhadap pajak penghasilan pada perusahaan manufaktur yang terdaftar di Bursa Efek Indonesia periode 2015-2019. Populasi dalam penelitian ini adalah perusahaan manufaktur tahun 2015-2019 yang berjumlah 155 perusahaan.Tehnik pengambilan sampel dalam menggunakan tehnik purposive sampling sehingga di peroleh sampel berjumlah 10 perusahaan.Tehnik analisis data menggunakan analisis regresi Linier Berganda.Berdasarkan hasil uji t dengan SPSS IBM 20 di peroleh hasil bahwa struktur modal yang di proksikan dengan DER berpengaruh terhadap pajak penghasilan Karena nilai thitung lebih besar dari $t_{\text {tabel }}(3.236>2.013)$ dan nilai signifikan $(0.002>0.05)$, arus kas yang di proksikan dengan total kas berpengaruh terhadap pajak penghasilan karena nilai $t_{\text {hitung }}$ lebih besar dari $t_{\text {tabel }}(2.437>2.013)$ dan nilai signifikan $(0.019>0.05)$, dan piutang yang di proksikan dengan Receible Turnover tidakberpengaruh terhadap pajak penghasilan karena nilai t hitung lebih besar dari t tabel $(-1.670<2.013)$ dan nilai signifikan $(0.102>$ $0.05)$.
\end{abstract}

Kata kunci :Struktur Modal, Arus Kas, Piutang, Pajak Penghasilan.

\section{PENDAHULUAN}

Pasar modal merupakan sarana untuk berinvestasi yang dijadikan tempat terjadinya transaksi jual beli saham.Bursa Efek Indonesia (BEI) atau dikenal IDX merupakan bagian tak terpisahkan dari kegiatan berinvestasi saham di Indonesia.hingga kini, di Indonesia sudah lebih dari satu juta investor di pasar modal. Perusahaan Efek yang dapat melakukan kegiatan jual beli efek haruslah tercatat sebagai anggota bursa efek yaitu perantara pedagang efek (PPE) yang telah memperoleh izin usaha dari OJK dan mempunyai hak untuk mempergunakan sistem dan sarana Bursa Efek sesuai dengan 
peraturan Bursa efek, perusahaan yang go public dan sudah terdaftar di Bursa Efek Indonesia salah satunya perusahaan manufaktur. (www.idx.co.id)

Indonesia merupakan salah satu negara yang pernah mengalami krisis ekonomi, walaupun keadaan ekonominya telah pulih, tetapi relatif lambat pertumbuhannya jika di bandingkan dengan negara-negara tetangga.Penerimaan negara Indonesia bersumber dari kekayaan alam, pajak,bea dan cukai, penerimaan negara bukan pajak, hasil perusahaan snegara, dan sumber lain (Suandy, 2005).

Salah satu sumber penerimaan terbesar bagi Indonesia dari semua sumber penerimaan negara adalah pajak.Salah satu jenis pajak yaitu pajak penghasilan (PPh), yang dapat di kenakan langsung kepada wajib pajak yang terdiri dari orang pribadi, warisan, badan atau bentuk usaha tetap menurut undang-undang No 36 Tahun 2008 tentang pajak penghasilan.(Djuanda, 2009).pajak penghasilan merupakan pajak yang dikenakan kepada orang pribadi atau badan atas penghasilan yang diterima atau diperoleh dalam satu tahun pajak.Penghasilan yang dimaksud dapat berupa keuntungan usaha,gaji,honorium, hadiah dan yang lainnya.

Laporan keuangan merupakan struktur yang menyajikan posisi keuangan dan kinerja keuangan dalam suatu entitas.Tujuan umum dari laporan keuangan adalah untuk menyajikan informasi kepada pada pengguna mengenai posisi keuangan, kinerja keuangan, dan arus kas dari entitas untuk membuat keputusan ekonomis yakni salah satunya adalah pemerintah terkait dengan pajak.Terkait dengan hal tersebut laporan keuangan menyediakan informasi mengenai elemen dari entitas yang terdiri dari asset, kewajiban, beban, pendapatan, perubahan ekuitas dan arus kas.

Tarif pajak di Indonesia masih cukup besar jika dibandingkan dengan Negara lain di ASEAN. Perubahan tarif pajak di harapkan dapat mendorong pembentukan modal dan memicu iklim investasi yang baik. Setiap perusahaan membutuhkan pendanaan, pemenuhan dana tersebut dapat berasal dari sumber internal maupun eksternal. Keputusan pendanaan menjadi pertimbangan bagi manajer keuangan untuk memilih sumber dana perusahaan dari hutang atau menerbitkan saham, yang digunakan oleh perusahaan sebagai struktur modalnya. Dalam kenyataannya, banyak Struktur modal adalah bertujuan untuk memadukan sumber dana permanen yang selanjutnya digunakan perusahaan dengan cara yang diharapkan akan mampu memaksimumkan nilai perusahaan.Indikator yang digunakan untuk mengukur strukur modal adalah Debt to Equity Ratio.Kaitan struktur modal dengan pajak penghasilan yaitu: Kenaikan nilai perusahaan terjadi karena pembayaran bunga atas utang merupakan pengurangan pajak sehingga laba yang mengalir kepada investor menjadi semakin besar. 
Hasil penelitian yang berhubungan dengan struktur modal menunjukkan hasil yang berbedabeda.Hasil penelitian Rahmadani (2010) menunjukkan struktur modal berpengaruh terhadap pajak penghasilan (PPh). Hasil ini didukung oleh oleh penelitian Azhari (2015) menunjukkan kenaikan penggunaan hutang oleh perusahaan dapat diimbangi dengan pengelolaan aktiva yang tepat, cermat dan efisien akan meningkatkan laba yang juga akan memperbesar pajak penghasilan. Tinggi rendahnya laba akan menentukan tingkat pajak penghasilan. Semakin tinggi laba menandakan semakin besar pula pajak penghasilan yang harus dibayarkan oleh entitas.Hasil yang berbeda dilakukan oleh Septiani (2009) dan Mutrialisa (2019) menunjukkan bahwa struktur modal tidak berpengaruh terhadap Pajak penghasilan.

Hasil penelitian sebelumnya terkait dengan pajak penghasilan mengalami ketidak konsistenan adalah arus kas.Arus kas merupakan arus masuk dan keluar kas atau setara kas.Indikator yang digunakan arus kas operasi adalah arus kas operasi bersih.Hubungan Arus kas dengan pajak penghasilan di ungkapkan secara terpisah dan diklasifikasikan sebagai arus kas dari aktivitas operasi, kecuali jika secara spesifik dapat diidentifikasi sebagai aktivitas pendanaan dan investasi.Pajak penghasilan dikenakan atas transaksi yang menghasilakan arus kas dari aktivitas operasi, investasi, atau pendanaan dalam laporan arus kas.walaupun beban pajak penghasilan dapat dengan mudah diidentifikasi dengan aktivitas investasi atau pendanaan, tetapi arus kas yang bersangkutan sering kali tidak mudah diidentifikasidan dapat terjadi dalam periode yang berbeda dengan transaksi arus kas yang mendasarinya. Oleh karena itu, pajak yang dibayar biasanya diklasifikasikan sebagai arus kas dari aktivitas operasi.Namun, jika arus kas pajak tersebut dapat diidentifikasi dengan transaksi individual yang menimbulkan arus kas yang bersangkutan, maka diklasifikasikan sebagai aktivitas pendanaan atau investasi, sesuai dengan jenis aktivitas tersebut.Apabila arus kas pajak dialokasikan pada lebih dari satu jenis aktivitas, maka jumlah keseluruhan pajak yang dibayar harus diungkapkan.Diana (2016) dan Mutrialisa (2019) menyatakan bahwa arus kas berpengaruh terhadap pajak penghasilan.Sedangkan hasil yang berbeda dilakukan oleh Pangesti (2013) menemukan bahwa arus kas tidak berpengaruh terhadap pajak penghasilan.

Kenaikan atau penurunan piutang dagang menjadi faktor penentu dari arus kas dari aktifitas operasional jika dalam income statement mencerminkan pendapatan, maka arus kas dari aktivitas operasional mencerminkan pembayaran dari pelanggan perusahaan.Piutang merupakan bentuk penjualan yang dilakukan oleh suatu perusahaan dimana pembayarannya tidak dilakukan secara tunai, namun bersifat bertahap.Salah satu indicator yang digunakan berkaitan dengan piutang adalah Receivable Turnover.Penelitian Pangesti (2013) menunjukkan perputaran piutang berpengaruh terhadap 
pajak penghasilan.Perlakuan pajak penghasilan atas kerugian piutang menurut perpajakan merujuk pada piutang yang nyata-nyata tidak dapat tertagih meskipun telah dilakukan upaya-upaya penagihan yang maksimal.Pembebanan piutang dalam laporan laba rugi perusahaan diperbolehkan baik secara akuntansi maupun secara fiskal akan tetapi wajib pajak harus memperhatikan syarat-syarat yang harus dipenuhi secara fiskal, agar tidak dilakukannya koreksi fiskal oleh petugas pajak atas pembebanan piutang.Hasil yang berbeda dilakukan oleh Diana (2016) menunjukkan perputaran piutang tidak berpengaruh terhadap pajak penghasilan $(\mathrm{PPh})$.

Adanya hasil yang beragam dari dari hasil penelitian terdahulu yang sudah diuraikan sebelumnya, peneliti mengkaji ulang Pengaruh Struktur Modal, Arus Kas dan Piutang Terhadap Pajak Penghasilan (PPh) pada Perusahaan Manufaktur yang terdaftar di BEI.

\section{KAJIAN TEORI}

\section{Pasar Modal}

Riyanto (2001: 218), pasar modal adalah pasar dalam pengertian abstrak yang mempertemukan dua kelompok yang saling berhadapan tetapi kepentingan saling mengisi, yaitu calon pemodal (investor) disatu pihak dan emiten yang membutuhkan dana jangka menengah atau jangka panjang di pihak lain, atau dengan kata lain adalah tempat (dalam arti abstrak) bertemunya penawaraan dan permintaan dana jangka menengah dan jangka panjang, yang dimaksud dengan pemodal adalah perorangan atau lembaga yang menanamkan dananya dalam efek, sedangkan emiten adalah perusahaan yang menerbitkan efek yang ditawarkan kepada masyarakat.

Pasar modal dapat berfungsi sebagai alternatif penghimpunan dana selain sistem perbankan. Pasar modal memiliki peranan yang penting dalam pembangunan ekonomi, karena pasar modal sebagai salah satu sumber pembiayaan eksternal jangka panjang bagi dunia khususnya perusahaan yanggo public dan sebagai wahana investasi bagi masyarakat.

\section{Pajak Penghasilan}

Soeparman (2005) pajak adalah iuran wajib, berupa uang atau barang, yang dipungut oleh penguasa berdasarkan norma-norma hukum, guna menutup biaya produksi barang-barang dan jasa kolektif dalam mencapai kesejahteraan umum.Pajak merupakan hal yang tidak dapat dilepaskan dari tiap negara. Dengan kata lain, kewajiban pembayaran pajak merupakan kewajiban yang tidak dapat dihindari oleh setiap warga negara, dan bersifat mengikat setiap warga Negara untuk mematuhinya karena diatur dalam peraturan perundang-undangan. 
Pajak penghasilan termasuk dalam kategori sebagai pajak subjektif, artinya pajak dikenakan karena adanya subjeknya yakni yang telah memenuhi criteria yang telah ditetapkan dalam peraturan perpajakan.Apabila tidak ada subjek pajaknya, maka jelas tidak dapat dikenakan pajak penghasilan. Siti Resmi (2005:74) Pajak Penghasilan (PPh) adalah pajak yang dikenakan terhadap subjek pajak atas penghasilan yang diterima atau diperolehnya dalam sutu tahun pajak.

Menurut Undang-Undang Republik Indonesia Nomer 36 tahun 2008 tentang pajak penghasilan, yang menjadi subjek pajak penghasilan adalah:

1. Orang pribadi, kedudukan orang pribadi sebagai subjek pajak dapat bertempat tinggal atau berada di Indonesia ataupun luar Indonesia.

2. Warisan yang belum terbagi sebagai satu kesatuan menggantikan yang berhak. Dalam hal ini,warisan yang belum terbagi sebagai satu kesatuan merupakan subjek pajak pengganti, menggantikan mereka yang berhak yaitu ahli waris. Penunjukan warisan tersebut dimaksudkan agar pengenaan pajak atas penghasilan yang berasal dari warisan tersebut tetap dapat dilaksanakan, demikian juga dengan tindakan penagihan selanjutnya.

3. Badan

Pengertian badan adalah sekumpulan orang dan atau modal yang merupakan kesatuan baik yang melakukan usaha maupun yang tidak melakukan usaha yang meliputi, Perseroan Terbatas (PT). Perseroan komanditer (CV), Badan Usaha Milik Negara atau Daerah dengan nama dan dalam bentuk apapun, persekutuan, firma, kongsi, koperasi, yayasan, lembaga, dana pension, bentu usaha tetap, dan bentuk badan lainnya.

\section{Struktur Modal}

Struktur modal menurut Joel G Siegel dan Jae K Shim (Fahmi 2015:179) adalah komposisi saham biasa, saham preferern, dan berbagai kelas seperti itu, laba yang di tahan, dan utang jangka panjang yang di pertahankan oleh kesatuan usaha dalam mendanai aktiva. Sehingga dapat di mengerti bahwa struktur modal merupakan gambaran dari bentuk proporsi financial suatu perusahaan yaitu antara modal yang di miliki yang bersumber dari utang jangka panjang (long term liabities)dan modal sendiri (shareholders' equty) yang menjadi sumber pembiayaan suatu perusahaan.

Kebutuhan dana untuk memperkuat struktur modal suatu perusahaan dapat bersumber dari internal dan eksternal, dengan ketentuan sumber dana yang di butuhkan tersebut bersumber dari tempat yang di anggap aman (safety position) dan jika di pergunakan memiliki nilai dorong dalam memperkuat struktur modal keuangan perusahaan. Dalam arti ketika dana itu di pakai untuk 
memperkuat struktur modal perusahaan, maka perusahaan mampu mengendalikan modal tersebut secara efektif dan efisien serta tepat sasaran.

\section{Arus Kas}

Menurut PSAK No.2 Arus kas adalah arus kas masuk dan arus kas keluar atau setara kas.Kas terdiri dari saldo (cash onhand) dan rekening giro.Setara kas (cash equivalent) adalah investasi yang sifatnya sangat likuid, berjangka pendek dan yang dengan cepat dapat di jadikan kas dengan jumlah tertentu tanpa menghadapi risiko perubahan nilai yang signifikan. Setara kas dimiliki untuk memenuhi komitmen jangka pendek, bukan untuk investasi atau tujuan lain. Sedangkan menurut Brighman (2001), arus kas bersih adalah kas aktual yang dihasilkan oleh perusahaan dalam satu tahun tertentu.namun, kenyataan bahwa perusahaan menghasilkan arus kas yang tinggi tidak berarti jumlah kas yang di laporkan di neraca juga tinggi.Tujuan utama arus kas adalah memberikan informasi tentang penerimaan kas dan pembayaran kas suatu entitas selama periode tertentu.Menurut Sumarsan (2013:23) menyatakan bahwa arus kas terdiri dari tiga komponen yaitu sebagai berikut:

a) Aktivitas Operasi merupakan arus kas dari kegiatan operasional menunjukan nilai kas bersih yang di peroleh dari hasil penjualan barang ataupun jasa perusahaan setelah di kurangi kas yang harus di keluarkan untuk memproduksi dan menjual produk ataupun jasa itu.

b) Aktivitas investasi merupakan sumber atau penggunaan kas dari kegiatan investasi menunjukan jumlah kas yang di keluarkan perusahaan untuk membeli barang ekuitas seperti peralatan baru, mobil, computer, dan mesin baru.

c) Aktivititas pendanaan merupakan arus kas dari aktivitas pendanaan menggambarkan pergerakan kas akibat adanya pendanaan atau pengembalian dana dari atau kepada pemegang saham atau calon pemegang saham atau dari pihak kereditur.

Informasi arus kas membantu para pemakai untuk memahami hubungan antara laba dan arus kas serta untuk memprediksi arus kas operasidi masa depan. Seperti pengaruh investor sebelumnya terhadap arus kas, bagaimana pengeluaran modal dibiayai serta jumlah hutang yang di terbitkan atau ditarik.Informasi arus kas juga membantu menjelaskan perubahan dalam akun neraca, seperti kenaikan hutang jangka panjang dan apakah kas terpengaruh karenanya

\section{Piutang}

Piutang merupakan tagihan si penjual kepada si pembeli sebesar nilai transaksi penjualan. Piutang bisa juga timbul apabila perusahaan member pinjaman sejumlah uang kepada pihak lain. Dengan demikian, piutang pada hakikatnya merupakan hak untuk menerima sejumlah uang di waktu yang akan datang yang timbul dari transaksi pada saat ini. Piutang merupakan milik perusahaan dan 
dengan demikian merupakan asset perusahaan.Piutang merupakan asset perusahaan. Setiap transaksi piutang selalu melibatkan dua pihak yaitu: Kreditur ( yaitu pihak yang mendapatkan piutang atau tagihan sebuah asset) dan Debitur (yaitu pihak yang berkewajiban membayar utang sebuah ). (Alharyono, 2011: 70) Untuk mengukur piutang pada

Piutang bisa dikelompokan menjadi tiga golongan, yaitu:

1. Piutang usaha

Tagihan perusahaan kepada konsumen yang melakukan transaksi secara kredit. Perusahaan biasanya mengharapkan akan dapat menerima kas dari transaksi tersebut dalam waktu 30-60 hari. Piutang usaha biasanya merupakan jenis tagihan yang paling signifikan dalam perusahaan.

2. Piutang wesell

Tagihan perusahaan yang didukung dengan instrument formal sebagai bukti tagihan yang disebut surat wesel. Piutang wesel biasanya memiliki jangka waktu pelunasan yang lebih panjang dari pada piutang usah, yaitu sekitar 60-90 hari atau bahkan lebih panjang, dengan kewajiban bagi si debitur untuk membayar bunga.

3. Piutang Lain-lain

Mencangkup semua tagihan yang bukan piutang usaha. Termasuk dalam jenis piutang ini adalah piutang yang timbul dari pemberian pinjaman kepada pihak lain, pinjaman kepada para karyawan,uang muka gaji kepada karyawan, dan uang muka pajak ( pajak yang di tangguhkan). (Jusuf 2011: 71-72).

\section{Pengembangan Hipotesis}

Menurut IAI (2009) laporan keuangan merupakan struktur yang menyajikan posisi keuangan dan kinerja keuangan dalam suatu entitas.Tujuan umum dari laporan keuangan adalah untuk kepentingan umum, yaitu menyajikan informasi mengenai posisi keuangan, kinerja keuangan, dan arus kas dari entitas untuk membuat keputusan ekonomis.Untuk mencapai tujuan ini, laporan keuangan menyediakan informasi mengenai elemen dari entitas yang terdiri dari asset, kewajiban, beban, pendapatan, perubahan ekuitas dan arus kas.

Struktur modal bertujuan memadukan sumber dana permanen yang selanjutnya di gunakan perusahaan dengan cara yang diharapkan akan mampu memaksimumkan nilai perusahaan. Bagi sebuah perusahaan sangat dirasa penting untuk memperkuat kestabilan keuangan yang dimilikinya, karena perubahan dalam struktur modal di duga bisa menyebabkan perubahan nilai perusahaan (Fahmi, 2015:18).Indikator yang digunakan untuk mengukur strukur modal adalah Debt to Equity Ratio. 
Hasil penelitian Rahmadani (2010) menemukan bahwa struktur modal yang di proksikan dengan Long term Debt to Total Asset Ratio (LDAR) dan Debt to Equity Ratio (DER)berpengaruh terhadap Pajak Penghasilan, dimana kenaikan nilai perusahaan terjadi karena pembayaran bunga atas utang merupakan pengurangan pajak sehingga laba yang mengalir kepada investor menjadi semakin besar. Hasil penelitian ini diperkuat oleh Azhari (2015) menemukan adanya penaruh signifikan struktur modal terhadap Pajak Penghasilan (PPh).

Brighman (2001) Arus kas bersih adalah kas aktual yang dihasilkan oleh perusahaan dalam satu tahun tertentu.Namun, kenyataan bahwa perusahaan menghasilkan arus kas yang tinggi tidak berarti jumlah kas yang di laporkan di neraca juga tinggi.Laporan arus kas merupakan satu bagian dari set laporan keuangan perusahaan yang berisi informasi yang menggambarkan arus kas masuk dan kas keluar perusahaan selama satu periode. (Suwardjono, 2006:84) menyatakan bahwa berdasarkan informasi dalam laporan arus kas, pemakai dapat memperoleh informasi untuk tujuan mengepaluasi kegiatan manajemen dalam operasi (operating), investasi (investing), dan pendanaan (Financing).

Diana (2016) menemukan pengaruh arus kas terhadap pajak penghasilan.Pajak penghasilan dikenakan atas transaksi yang menghasilkan arus kas dari aktivitas operasi, investasi, atau pendanaan dalam laporan arus kas.walaupun beban pajak penghasilan dapat dengan mudah diidentifikasi dengan aktivitas investasi atau pendanaan, tetapi arus kas yang bersangkutan sering kali tidak mudah diidentifikasidan dapat terjadi dalam periode yang berbeda dengan transaksi arus kas yang mendasarinya. Oleh karena itu, pajak yang dibayar biasanya diklasifikasikan sebagai arus kas dari aktivitas operasi.Hasil penelitian ini diperkuat oleh Mutrialisa (2019) menemukan adanya pengaruh signifikan arus kas terhadap pajak penghasilan (PPh).

Hasil penelitian Pangesti (2013) menunjukkan bahwa Piutang berpengaruh terhadap Pajak Penghasilan (PPh).Piutang merupakan bentuk penjualan yang dilakukan oleh suatu perusahaan dimana pembayarannya tidak dilakukan secara tunai, namun bersifat bertahap.Penjualan piutang artinya lebih jauh perusahaan menerapkan manajemen kredit. Dan salah satu target dari manajemen kredit adalah tercapainya target penjualan sesuai dengan perencanaan, serta selanjutnya menunggu masuknya dan angsuran ke kas perusahaan. (Fahmi, 2015: 62-63).

Berdasarkan uraian diatas maka dapat dibuat hipotesis dalam penelitian ini adalah:

$\mathrm{H}_{1,2}$ dan 3 : Terdapat pengaruh Struktur Modal, Arus kas dan Piutangsecara parsial terhadap Pajak Penghasilan. 


\section{METODE PENELITIAN}

\section{Jenis Penelitian, Populasi, Sampel dan Teknik Pengambilan Sampel}

Jenis penelitian yang digunakan adalah penelitian asosiatif/hubungan.Populasi penelitian ini adalah seluruh perusahaan manufaktur yang terdaftar di Bursa Efek Indonesia.Pengambilan sampel dilakukan dengan menggunakan metode purposive sampling dimana teknik penentuan sampel dengan pertimbangan tertentu.Adapun jumlah sampel penelitian ini adalah 10 perusahaan selama tahun 2015-2019.

\section{Indentifikasi Variabel Penelitian}

\section{Variabel Independen}

Variabel independen merupakan variable yang mempengaruhi variable dependen. Dalam penelitian ini terdapat 3 variabel independen yaitu sebagai berikut:

\section{Struktur Modal}

Struktur modal adalah komposisi saham biasa, saham prefern, dan berbagai kelas seperti itu, laba yang ditahan, dan utang jangka panjang yang di pertahankan oleh kesatuan usaha dalam mendanai aktiva (fahmi, 2015:179).

Adapun rumus yang digunakan adalah:

$$
\frac{\text { Total Liabilities }}{\text { Stockholders'Equity }}
$$

(Sumber: Fahmi, 2015:182

Keterangan:

Total Liabilities $\quad=$ Total utang

Stockholders' Equity = Modal sendiri

\section{Arus Kas}

Menurut PSAK No.2, Arus kas adalah arus kas masuk dan arus kas keluar atau setara kas. Kas terdiri dari saldo (cash onhand) dan rekening giro.Setara kas (cash equivalent) adalah investasi yang sifatnya sangat likuid, berjangka pendek dan yang dengan cepat dapat di jadikan kas dengan jumlah tertentu tanpa menghadapi risiko perubahan nilai yang signifikan.

Adapun rumus yang digunakan: 


$$
\mathrm{CFO}=\text { CFO Masuk }- \text { CFO Keluar }
$$

(sumber: Sinaga, 2010)

$\mathrm{CFO}=$ Arus kas operasi

\section{Piutang}

Piutang adalah bentuk penjualan yang dilakukan oleh suatu perusahaan dimana pembayarannya tidak dilakukan secara tunai, namun bersifat bertahap.Penjualan piutang artinya lebih jauh perusahaan menerapakan manajemen kredit.dan salah satu target dari manajemen kredit adalah tercapainya target penjualan sesuai dengan perencanaan, serta selanjutnya menunggu masuknya dana angsuran ke kas perusahaan.

Adapun rumus yang digunakan adalah:

$$
\text { Receivable turnover }=\frac{\text { penjualannetokredit }}{\text { rata-ratapiutang }} \times 100 \%
$$

$$
\text { (Sumber: Jusuf, } 2014: 76 \text { ) }
$$

\section{Variabel Dependen (Y)}

Variabel dependen adalah variable yang dipengaruhi oleh variable independen.Dalam penelitian ini Pajak Penghasilan (PPh) Badan.Pajak Penghasilan (PPh) Badan terutang adalah pajak yang dikenakan terhadap laba yang dihasilkan atau diperoleh perusahaan satu tahun pajak. Dengan kata lain PPh Badan Terutang adalah laba fiscal yang sudah direkonsiliasi dikali dengan tarif PPh badan terutang. Dalam alporan keuangan PPh Badan terutang sering disebut beban pajak kini.

\section{Teknik Analisis Data}

Tehnik analisis data dalam penelitian ini menggunakan analisis regresi linier berganda.Analisis regresi linier berganda adalah analisis untuk mengukur besarnya pengaruh antara dua atau lebih variabel independen terhadap satu variabel dependen (Priyanto, 2012:127) Penelitian ini menggunakan analisis regresi linier berganda karena menggunakan tiga variabel bebas dan satu variabel terikat. Maka persamaan regresi liniernya sebagai berikut :

$$
\mathrm{Y}=\mathrm{a}+\mathrm{b} 1 \mathrm{X} 1+\mathrm{b} 2 \mathrm{X} 2+\mathrm{b} 3 \mathrm{X} 3+\mathrm{e}
$$

Keterangan :

$$
\begin{array}{ll}
\mathrm{Y} & =\text { Pajak Penghasilan } \\
\mathrm{a} & =\text { Konstanta } \\
\mathrm{b} 1-\mathrm{b} 3 & =\text { Koefisien }
\end{array}
$$




$$
\begin{array}{ll}
\mathrm{X} 1 & =\text { Struktur Modal } \\
\mathrm{X} 2 & =\text { Arus Kas } \\
\mathrm{X} 3 & =\text { Piutang } \\
\mathrm{e} & =\text { Error }
\end{array}
$$

\section{ANALISIS DAN PEMBAHASAN}

\begin{tabular}{|c|c|c|c|c|c|c|}
\hline \multicolumn{7}{|c|}{ SCoefficients ${ }^{a}$} \\
\hline \multirow{2}{*}{\multicolumn{2}{|c|}{ Model }} & \multicolumn{2}{|c|}{ Unstandardized Coefficients } & $\begin{array}{l}\text { Standardized } \\
\text { Coefficients }\end{array}$ & \multirow[t]{2}{*}{$\mathrm{T}$} & \multirow{2}{*}{ Sig. } \\
\hline & & $\mathrm{B}$ & Std. Error & Beta & & \\
\hline \multirow{4}{*}{1} & (Constant) & 961.375 & 389.196 & & 2.470 & .017 \\
\hline & STRUKTUR MODAL & 167.575 & 51.789 & .407 & 3.236 & .002 \\
\hline & ARUS KAS & -30.602 & 12.560 & -.321 & -2.437 & .019 \\
\hline & PIUTANG & -599.064 & 358.803 & -.213 & -1.670 & .102 \\
\hline
\end{tabular}

Hasil Analisis regresi linier berganda dengan menggunakan bantuan program SPSS 22. Diperoleh hasil sebagai berikut:

\section{Hasil Uji Regresi Linier berganda}

a. Dependent Variable: PPh

Sumber: data yang sudah di olah (2021)

Dari hasil analisis pada tabel di atas dapat di susun persamaan regresi adalah sebagai berikut $\mathrm{Y}=961.375+167.575 \mathrm{X} 1+-30.602 \mathrm{X} 2+-599.064 \mathrm{X} 3+\mathrm{e}$

Berdasarkan tabel di atas menunujukan hasil bahwa penelitian ini mampumemberikan bukti secara empiris adanya pengaruh yang signifikan antara variable struktur modal dan arus kas terhadap Pajak Penghasilan, sedangkan variable independen lainnya Piutang terbukti tidak mempunyai pengaruh yang signifikan.

Hasil uji parsial terhadap Struktur modal yang diproksikan dengan Debt to Equity Ratio (DER) diperoleh $t_{\text {hitung }}$ sebesar 3,236 dengan $t_{\text {tabel }}$ 2,013 dan tingkat signifikansi 0,002. Jadi Struktur modal berpengaruh terhadap Pajak Penghasilan $(\mathrm{PPh})$ yang ditunjukkan oleh $\mathrm{t}_{\text {hitung }}(3,236)>\mathrm{t}_{\text {tabel }}(2,013)$ dengan tingkat signifikansi 0,002 yang berarti lebih kecil dari $0,05(0,002<0,05)$. Struktur modal berpengaruh terhadap pajak penghasilan (PPh) pada perusahaan manufaktur yang terdaftar di Bursa Efek Indonesia periode 2015-2019. Hasil dari penelitian ini menunjukan bahwa struktur modal berpengaruh terhadap pajak penghasilan, hal ini di sebabkan karena kenaikan nilai perusahaan terjadi karena pembayaran bunga atas utang sehingga laba yang mengalir kepada investor semakin besar. 
Hasil penelitian ini konsisten dengan penelitian yang di lakukan oleh Rahmadani (2010) dan Azhari (2015) dengan hasil Struktur modal yang diproksikan dengan Debt to Equity Ratio (DER) berpengaruh secara signifikan terhadap Pajak Penghasilan (PPh).

Dari hasil penelitian Arus Kas di ketahui bahwa koefisien regresi sebesar -30,602 hasil statistic uji t dengan nilai $t_{\text {hitung }}$ sebesar -2,437 dan $t_{\text {tabel }}$ sebesar 2,013 (-2,437<2,013) dengan tingkat signifikansi sebesar 0,019(0,019<0,05). Maka dapat di simpulkan Arus Kas berpengaruh terhadap pajak penghasilan ( $\mathrm{PPh}$ ) pada perusahaan manufaktur yang terdaftar di Bursa Efek Indonesia periode 2015-2019.Hasil dari penelitian ini menunjukan bahwa arus kas berpengarus terhadap pajak penghasilan, hal ini di sebabkan karena perusahaan menghasilkan arus kas yang tinggi berarti arus kas yang di laporkan juga tinggi.Hasil penelitian ini konsisten dengan Penelitian yang di lakukan oleh Diana (2016) dan Mutrialisa (2019) dengan hasil arus kas berpengaruh secara signifikan terhadap pajak penghasilan $(\mathrm{PPh})$.

Hasil penelitian Piutang di ketahui bahwa koefisien regresi sebesar -599,064 hasil statistic uji t dengan nilai thitung sebesar -1,670 dan $\mathrm{t}_{\text {tabel }}$ sebesar 2,013 (-1,670<2,013) dengan tingkatsignifikansi sebesar 0,102 (0,102 > 0,05). Maka dapat di simpulkan bahwa hasil penelitian piutang tidak berpengaruh terhadap pajak penghasilan. Hasil dari penelitian ini menunjukan bahwa piutang tidak berpengaruh terhadap pajak penghasilan, Pajak penghasilan pada Perusahaan manufaktur yang terdaftar di Bursa Efek Indonesia periode 2015-2019 yang dijadikan sampel lebih dipengaruhi oleh factor lain selain dari dari piutang. Hasil Penelitian ini tidak mampu membuktikan secara empiris pengaruh piutang terhadap pajak penghasilan (PPh).Hasil penelitian ini tidak mendukung penelitian yang dilakukan Pangesti (2013) yang menemukan adanya pengaruh piutang terhadap pajak penghasilan.Tetapi hasil penelitian ini konsisten dengan penelitian penelitian yang dilakukan oleh Diana (2016) bahwa piutang tidak berpengaruh terhadap pajak penghasilan.

\section{SIMPULAN}

Berdasarkan hasil pembahasan pada bab sebelumnya, kesimpulan yang dapat diambil dari penelitian ini adalah Hasil pengujian secara parsial menunjukkan Struktur Modal dan Arus Kasberpengaruh terhadap Pajak Penghasilan (PPh) sedangkan Piutang tidak berpengaruh terhadap Pajak Penghasilan (PPh)

\section{REFERENSI}


Azhari, Andi. 2015. Pengaruh Struktur Modal dan Manajemen Laba Terhadap Pajak Penghasilan Badan Terutang.Skripsi Universitas Islam Negeri Syarif Hidayatullah Jakarta.

Brigham, Eugene, F dan Joel F Houston. 2001. "Manajemen Keuangan”, Erlangga, Jakarta.

Brotodihardjo, R. Santoso. " Pengantar Ilmu Hukum Pajak". PT Rafika Aditama.Edisi ke empat. Bandung. 2003.

Diana, P. A. 2016. Pengaruh Perputaran Kas, Piutang Persedian Terhadap Profitabilitas Pada Perusahaan Semen di BEI.Jurnal Ilmu \& Riset Manajemen, 5 (3).

Djuanda, Gustian dan Irwansyah Lubis. 2009. "Pelaporan Pajak Penghasilan", PT. Pustaka Utama. Jakarta.

Fahmi, Irham. 2015. “Analisis Laporan Keuangan”. Cetakan ke lima. Alfabeta, Bandung.Anggota Ikatan Penerbit Indonesia (IKAPI).

Ghozali, Imam. 2012. Aplikasi analisis multivariate dengan program SPSS. Semarang :Badan Penerbit USSniversitas Diponogoro.

Jusuf, Alhariyono. 2014. “Dasar-Dasar Akuntansi JILID 2". Sekolah Tinggi Ilmu Ekonomi YKPN. Jogjakarta.

Pajak, Undang-Undang Nomor 17 Tahun 2000.

Pangesti, Ayu Eka.2013. Pengaruh Perputaran kas, piutang dan persedian terhadap profitabilitas dan likuiditas.Undergraduate thesis. STIE PERBANAS SURABAYA.

Pernyataan Standar Akuntansi (PSAK) No. 2 Paragraf 9.

Priyatno,dwi 2012. Belajar analisis data dengan SPSS 20.Yogyakarta: ANDI.

Rahmadani, Endah Nilam. 2010. Analisis pengaruh struktur modal terhadap pajak penghasilan (PPh) Badan terutang. Skripsi.Universitas Islam Negeri Syarif Hidayatullah Jakarta.

Republik Indonesia, Undang-Undang Nomor 36 Tabun 2008 tentang Pajak Penghasilan.

Resmi, Siti. 2005. "Perpajakan: Teori dan Kasus", Salemba Empat, Jakarta.

Riyanto, Bambang. 2001. 'Dasar-dasar Pembelajaran Perusabaan”, BPFE, Yogyakarta.

Septiani, Mutrialisa. 2019. Analisis Pengaruh Modal Sendiri dan Hutang Jangka Panjang Terhadap Pph Badan Terutang.

Sinaga, Hardian Hariono. 2010. Analisis Pengaruh Total Arus Kas, Komponen Arus Kas, Laba Akuntansi terhadap Return Saham. Semarang. Universitas Diponorogo.

Suandy, Early.2005. "Hukum Pajak”, Salemba Empat, Jakarta.

Sugiyono.2014. Metode Penelitian Kuantitatif dan Kualitatif. Alfabeta, Bandung.

Sumarsan, Thomas. 2013. "Akuntansi Dasar dan Aplikasi Dalam Bisnis". Versi IFRS Jilid 1.Jakarta; Indeks.

Suwardjono.2006. Teori Akuntansi Perekayasaan Pelaporan Kenangan Edisi ke 3. Yogjakarta:BPFE.

www.idx.co.id (diakses pada tanggal 3 Pebruari). 